\title{
Communitarian education and mathematics learning: A way of value diversity
}

\author{
Natividad Adamuz-Povedano ${ }^{\text {1a }}$, Veronica Albanese ${ }^{2}$, and Rafael Bracho-López ${ }^{1}$ \\ ${ }^{1}$ Universidad de Córdoba, San Alberto Magno s/n, Córdoba, 14004, Spain \\ ${ }^{2}$ Universidad de Granada, Campus Cartuja s/n, Granada 18071, Spain
}

\begin{abstract}
In our society there is high diversity so we need educational methodologies that promote equal opportunities for personal success inside the difference. It is necessary to explore the role of non-formal educational practices in multicultural contexts and to implement a model of communitarian education that allows the practices of other cultures to become valued by and visible to the broader society. Nowadays there are not doubts about the importance of the developing of number sense in the early mathematics learning, however, the entrance to the scholar arithmetic is, in most cases, through the teaching of the four rules using the traditional algorithms. Here we show how to use open calculations based on numbers $(\mathrm{ABN})$ as an inclusive methodological alternative, based on the meaningful learning of the decimal system, the operations and their properties. We think the method fits very well with people from other ethnics as Romanian people.
\end{abstract}

\section{Introduction and contextualization}

Education, especially in its compulsory level, is understood as a prerequisite for inclusion, but in some cases it can be a pathway to exclusion. In this paper we present the beginning of a research that intend to take into account culture in the teaching-learning process, focusing on a specific topic of Mathematics, the scholar arithmetic.

The research is sited in a Primary School and its surrounding area. The community is formed by an agglomeration of 3000 people distributed among 520 houses, and situated in the outskirts of Córdoba city, in Spain. Unemployment is one of the biggest problems in the community.

Recent statistics show that $60 \%$ of the people in the community are unemployed, causing high rates of poverty, marginalization and a soaring risk of school truancy. More than half of the population of the community is illiterate.

\footnotetext{
${ }^{a}$ Corresponding author: nadamuz@uco.es
} 
In 2011-2012 the school began its transformation to become a Learning Community, which resulted in a significant reduction of truancy. In this year there are 120 students enrolled in the school, most of them Romanian children.

In a general way, a learning community is a group of people who learn together, but we mean more than this, it's a specific model which means to agree on a common vision, basic values and objectives of school development, it increases the commitment of pupils, teachers, parents and other stakeholders and supports school quality and development [3].

As it became a Learning Community, the school opened its doors to the local community. This transformation has favored important changes in the families who have been voluntarily participating in the communitarian educational activities. At the same time, new methodological strategies like dialogic learning and communitarian mediation have been adopted.

\section{Framework}

In our classrooms there is high diversity that requires solutions to help us to assist our students; we need methodologies that promote equal opportunities for personal success inside the difference. Interculturality represents a manner of being, a way of living in and make commitments with a city [10].

Mathematical knowledge can be divided into two categories: informal and formal. Informal mathematics is that relative to knowledge and skills that children have acquired in their social environment, outside school context. On the other hand, the formal mathematical is referred to knowledge and skills acquired at school. Mathematical knowledge is the result of both formal and informal experiences [5], so we need to build bridges between the learning experiences of children outside and inside of school.

There are several inquiries about calculation in Romanian communities [2, 9 and 10] that agree Romanian people have developed a great mental arithmetic skills, although, in most case, they are not able to read. Children work with their parents in the market and they are able to do a lot of operations but they do not get success in scholar mathematics.

From this point of view, it is necessary a change on the field of scholar Mathematics, the failure of mathematics alphabetization in the early years of learning can produce indelible marks on the person. So, we emphasize how relevant is to start using integrated methodologies which not label a student as "able" or "not able" to mathematics.

Nowadays there are not doubts about the importance of the developing of number sense in the early mathematics learning [ 1 and 5], however, the entrance to the scholar arithmetic is, in most cases, through the teaching of the four rules using the traditional algorithms, in the same way for ages. Maier asserts that students need to know these procedures not because of their mathematical import but because they help students be successful in school [6].

In this study we present a methodology that uses open calculations based on numbers $(\mathrm{ABN})$ as an inclusive alternative, based on the meaningful learning of the decimal system and in the comprehensive mastery of the operations and their properties. These algorithms were created by Jaime Martinez Montero [7]. They are called Open calculations based on numbers:

- Open because students can solve operation by different ways, according to their skills.

- Based on Numbers and not on ciphers, it let students to be aware about the size of the number.

We have found that this method fits very well with people from other ethnics as Romanian people. 


\section{Objective}

The main general objective of the research is to explore the role of non-formal educational practices in multicultural contexts and to implement a model of communitarian education that allows the practices of other cultures to become valued by and visible to the broader society.

\section{Methodology}

The inquiry is a model of participatory action research based on critical communicative research methodology, studying the processes of social and cultural transformation that will take place at various stages [4]. The choice of a critical perspective is because it fosters transformation, in addition to understanding and interpreting reality. While the communicative perspective is based on interactions and communication to promote such a transformation; reflection and self-reflection from the voices and interpretations of the people, who the research is directed to, are also included. Thus, we seek not only the development of scientific knowledge but also the transformation of a reality marked by social exclusion and inequality.

\section{Results}

We are working in the following directions:

- There is a space for the cultural issues: initiatives arising in the Learning Communities project are generating dynamics of participation that influence the redefining of the school as a privileged space for cultural diversity, giving voice for example to the cultural ability in mental calculation of the Romanian people.

- The multiplicities of interactions generated in the school space are changing the beliefs of teachers, families and volunteers involved in the school transformation.

An added value of the experience is that the context around the school could reflect the transformation process of the school itself, but there is still a lot of work to do on this sense.

\section{References}

1. Bracho-López, R., Gallego-Espejo, M., Adamuz-Povedano, N., \& Jiménez-Fanjul, N., Impacto Escolar de la Metodología Basada en Algoritmos ABN en Niños y Niñas de Primer Ciclo de Educación Primaria. Unión. Revista Iberoamericana de Educación Matemática, 29, 97-109 (2014)

2. Cadeia, C., Palhares, P., \& Sarmento, M., As crianças ciganas nas feiras e na escola- os seus métodos de cálculo mental. Quadrante, XIX(1), 71-92 (2010)

3. Díez-Palomar, J., \& Flecha, R., Comunidades de Aprendizaje: un proyecto de transformación social y educativa. Revista Interuniversitaria de Formación de Profesorado, 24(1), 19-30 (2010)

4. Freire, P., Pedagogy of the oppressed. New York: Herder and Herder (1970)

5. Ginsburg, H., \& Baroody, A. J., Tema-3: test de competencia matemática básica. (M. . Núñez del Río \& T. Lozano Guerra, Eds.). Madrid: TEA ediciones (2007)

6. Maier, E. A., Basic Mathematical Skills or School Survival Skill? Teaching Children Mathematics, 2 (1987)

7. Martínez, J., Una nueva didáctica del cálculo para el siglo XXI. Barcelona: CissPraxis (2000) 
8. Pereira, G., Educaçao Matemática no Pré-escolar: Significaçao para uma comunidade de etnia Cigana. Universidade de Lisboa (2011)

9. Pereira, G., \& Moreira, D., Cálculo mental: estratégias de "escape" dos alunos ciganos a o uso dos algoritmos escolares. In XVI SIEM Actas 2005 (pp. 253-272). Lisboa: Associação de Professores de Matemática (2005)

10. Zapata-Barrero, R., Hacia un nuevo concepto de ciudadanía. Revista Anthropos, 191, 3-20 (2001) 